\title{
The Sovereign Debt Crisis and the Evolution of Labour Law in Europe
}

Link to publication record in Manchester Research Explorer

\section{Citation for published version (APA):}

Deakin, S., \& Koukiadaki, A. (2013). The Sovereign Debt Crisis and the Evolution of Labour Law in Europe. In N. Countouris, \& M. Freedland (Eds.), Resocialising Europe in a Time of Crisis Cambridge University Press.

\section{Published in:}

Resocialising Europe in a Time of Crisis

\section{Citing this paper}

Please note that where the full-text provided on Manchester Research Explorer is the Author Accepted Manuscript or Proof version this may differ from the final Published version. If citing, it is advised that you check and use the publisher's definitive version.

\section{General rights}

Copyright and moral rights for the publications made accessible in the Research Explorer are retained by the authors and/or other copyright owners and it is a condition of accessing publications that users recognise and abide by the legal requirements associated with these rights.

\section{Takedown policy}

If you believe that this document breaches copyright please refer to the University of Manchester's Takedown Procedures [http://man.ac.uk/04Y6Bo] or contact uml.scholarlycommunications@manchester.ac.uk providing relevant details, so we can investigate your claim.

\section{OPEN ACCESS}




\title{
The sovereign debt crisis and the evolution of labour law in Europe
}

\author{
SIMON DEAKIN AND ARISTEA KOUKIADAKI
}

\section{Introduction}

The sovereign debt crisis, which began in Greece in 2010 and then spread to several other Eurozone economies, is having profound consequences for the labour law systems of the debt-affected Member States and for the role of social policy in EU law and governance. As a result of the austerity measures stipulated in the loan agreements made between the 'Troika' of the IMF, ECB and Commission, and the Member States receiving financial assistance, essential features of national systems of labour law and social security have been, or are in the course of being, radically revised. These 'structural' reforms are leading to a worsening of living and working conditions and a deepening of economic recession. Under these circumstances, current efforts to amend the framework of EU law and governance in such a way as to embed fiscal discipline in the Eurozone, epitomised by the 'Six Pack' of economic regulations and the Treaty on Stability, Coordination and Governance, risk inducing a continent-wide 'race to the bottom' in labour standards.

In this chapter we seek to put the sovereign debt crisis in the context of the long-run evolution of labour law systems in Europe as well as more recent institutional developments at EU level. We argue that notwithstanding the absence of an EU-level labour code that would have put a floor under national labour law systems, the experience of European labour law from the early 1970s onwards has been one of stability (with the UK being the most prone to change), and the maintenance of a significantly higher level of protection than in the US. Even with the gradual implementation of the programme of the economic and monetary union from the Treaty of Maastricht onwards, and the deepening of internal market reforms, labour law at Member State level did not undergo a fundamental change (section 2). We argue that part of the reason for this was a fundamental compatibility of labour law protection with the 
competitiveness agenda which came to influence national and European policy-making at this time. However, labour law regulation was unable to reverse the trend towards weaker collective bargaining systems and falling union density, and these developments, as they weakened the force of labour law protections on the ground, were responsible at least in part for the increase in inequality experienced in the large EU economies, as well as in the US, during this period. In section 3 we provide a brief overview of the processes through which the effects of the crisis, which began in financial markets, were transmitted to labour markets through the interventions of the Troika, and how this was a response framed by an increasingly neo-liberal policy orientation within EU law relating to the internal market and to economic and monetary union. In section 4 we examine the main trends of deregulation in the debt-affected States since the interventions of the Troika began in 2010. In section 5 we offer an assessment of the likely prospects for European social policy in the light of the preceding analysis.

\section{European labour law prior to the crisis: social policy in an increasingly neo-liberal economic framework}

As is well known, the founders of the European Union took the decision, at the outset of the formation of the EEC in the mid-1950s, that labour law and social policy would operate essentially at the level of the Member States, with only limited harmonisation at transnational level. ${ }^{1}$ This decision was reflected in the marginal place accorded to social policy in the Treaty of Rome. Although the 1970s saw the adoption of significant directives in the areas of equal pay and employment protection and a greater role for the Court of Justice in articulating social rights, while the competences of the Union in the social policy sphere were extended in the Single Act (1986) and the Treaties of Maastricht (1992) and Amsterdam (1997), a comprehensive European labour code did not emerge from this process. Despite substantial progress in the areas of health and safety, collective employee representation, flexible working and equality of treatment during the 1990s and early 2000s, there remained many areas of domestic labour law which were not underpinned by any floor

1 See, generally, S. Deakin, 'Labour Law as Market Regulation: the Economic Foundations of European Social Policy', in P. Davies, A. Lyon-Caen, S. Sciarra and S. Simitis (eds.), Principles and Perspectives on EC Labour Law: Liber Amicorum for Lord Wedderburn (Oxford University Press: 1996), pp. 63-93. 
of rights or minimum harmonising measure at European level. Certain issues which were core to domestic labour law systems, including wage regulation, freedom of association and the right to strike, were explicitly excluded from the competences of the Union.

The adoption of the programme for economic and monetary union following the Treaty of Maastricht was a turning point for the Union and for its social policy. From this point on, Member States were increasingly locked into a macroeconomic policy framework that was dictated by the terms upon which the single currency was to be constructed. These included a commitment to price stability and balanced budgets, which was to be policed by the Union institutions under the terms of the Stability and Growth Pact. ${ }^{2}$ Once the single currency was in place, Member States of the Eurozone formally lost the ability to use exchange rate flexibility as a response to economic shocks, and were tied into the interest rate policy of the European Central Bank (ECB). The ECB's semi-autonomous position within the institutional structure of the Union was designed to preserve its independence from domestic economic policy concerns, and its mandate required it to prioritise price stability over other economic objectives including full employment, in contrast to the broader mandates given to other central banks such as the US Federal Reserve and the Bank of England. This was also a period when the EU's internal market programme was deepened through increasing legislation and court intervention, a process which led to the erosion of the autonomy of labour law and its increasing subjection to a deregulatory competition policy and internal market law. ${ }^{3}$

Advocates of the Euro expected it to lead to greater deregulation of national labour law regimes, once the administration by the ECB of the unified monetary policy exposed 'inefficiencies' and 'distortions' induced by excessive regulation. ${ }^{4}$ With the deepening of the single market programme, the implementation of currency union and the absence of a Europe-wide labour code or transnational floor of rights, institutional forces were clearly aligned in favour of greater deregulation. The 2000s

2 See S. Deakin and H. Reed, 'The Contested Meaning of Labour Market Flexibility: Economic Theory and the Discourse of European Integration', in J. Shaw (ed.) The Evolution of EC Social Policy (Oxford: Hart: 2000), pp. 71-99.

3 See S. Deakin, 'Regulatory Competition after Laval (2008-9) 10 Cambridge Yearbook of European Legal Studies 581-609.

4 On this, see A. Alesina, S. Ardagnana and V. Gallaso, 'The Euro and Structural Reforms', in A. Alesina and F. Giavazzi (eds.), Europe and the Euro (Boston, MA: NBER, 2010), pp. 57-93. 
were a period of stasis in legislative activity in the area of EU-level social policy, with few substantive measures adopted in the labour law field, while the pursuit of a policy of promoting employment growth through open methods of co-ordination placed Member States under further pressure to adopt policies of labour market flexibilisation.

However, domestic labour law regulation did not significantly diminish in its intensity or coverage during this period. The labour law systems of the EU Member States have mostly been stable since the early 1990s. This is not to confuse labour law regulation with the strength of organised labour or with the ability of trade unions to enforce labour standards on the ground. Labour law has continued to have a role in regulating the labour market at the same time as there have been significant declines in union density, which, in turn, have put in doubt the effectiveness of the law in practice. However, the empirical picture is not one of the disappearance or absence of labour law under the increasingly neo-liberal economic policy regime of the internal market and single currency after $1990 . .^{5}$

Comparisons across legal systems are necessarily problematic in so far as they seek to estimate the relative strength or weakness of labour law protections. So-called 'leximetric' coding techniques provide a basis on which the empirical variety of labour law regimes can be captured in such a way as to allow for systematic comparison on a cross-national basis and over time. Leximetric analysis shows that in Germany and France, protective labour law regulation, which was already substantial at the start of the 1970s, was strengthened further, particularly in the French case, in the course of the 1970s and 1980s, and saw only slight deregulatory changes, by comparison, during the 1990s and 2000s. ${ }^{6}$ The UK is unusual in the degree of variation of change experienced over time. The reforms of the Thatcher and Major Governments in the 1980s and early 1990s reduced legal protections almost to the minimal levels (by international standards) of the US, but from the mid-1990s, first under the influence of EU law and later during the period in office of the Labour Governments of Blair and Brown, labour law regulation in the UK began to revive, and by the mid-2000s was converging with the other large European

5 S. Deakin and F. Wilkinson, 'Marchés du travail, crise financière et réforme: projet d'agenda pour une politique du travail' (2011) 182 L'homme et la societé 25-52.

6 On the points made in this paragraph, see S. Deakin, P. Lele and M. Siems, 'The Evolution of Labour Law: Calibrating and Comparing Regulatory Regimes' (2007) 146 International Labour Review 133-62. 
economies. The UK is sometimes said to have a 'light touch' approach to labour law regulation along similar lines to that of the US, but the period of the mid-1990s aside, the extent of similarity with the US can be overstated. For example, in the area of employment protection, the UK has had mainland European-style unfair dismissal laws since the early 1970s. Notwithstanding some deregulatory reforms, including changes to the qualifying periods for dismissal protection and other exclusions affecting fixed-term, temporary and part-time workers, the core of the UK's unfair dismissal law has remained largely intact since that time. Although remedies for unfair dismissal are weaker in the UK than in some continental European countries, with reinstatement rarely awarded and compensation normally capped at low levels in relation to median earnings, the UK's position on dismissal protection is far removed from the employment at will approach which continues to prevail in the US. The level of dismissal protection in the UK has been similar, in functional terms, to that in Germany since the late 1970s. By European standards the UK is more of an outlier in relation to its collective labour laws, which remained weak even after the return of Labour Governments to office after 1997.

Nor did policies of labour market flexibilisation in the major mainland European economies during the 2000s bring about fundamental changes to labour law regimes. In Germany, the deregulatory 'Hartz' reforms of the mid-2000s, introduced under a social democratic-led coalition, mainly affected social security law, not employment law, and left the core of the German model of strong dismissal protection and collective worker representation more or less intact. Deregulatory initiatives in France under the Sarkozy presidency took the form of limited adjustments to the strict controls on working time introduced by Socialist administrations in the 1990s, and of efforts to exclude new hirings from the scope of dismissal protection, which were undermined by judicial rulings and then repealed. Although all the European systems, including the UK, modulated the effect of employment protection laws during this period by encouraging the growth of fixed-term and agency work outside the scope of core dismissal rights, they were also implementing, under EU pressure, laws mandating equal treatment in other respects for workers employed on flexible employment contracts, thereby reducing any cost advantage offered by these forms of employment by comparison to regular, full-time work. ${ }^{7}$ The claim that European systems have become more 'dualist' over

7 Deakin, Lele and Siems, 'The Evolution of Labour Law' 
time, with separate regimes applying for 'core' and 'marginal' workforces, is not clearly borne out in leximetric data.

The persistence of labour law regulation at national level notwithstanding the increasingly neo-liberal policy orientation of EU law and governance may reflect the continued political strength of organised labour, in particular in systems based on proportional representation which stress consensual policy-making and coalition building over 'winner takes all' politics, or simply inertia within the legal and political systems, which makes radical, market-orientated reforms difficult to implement. However, it may also be the case that labour laws survived despite the neo-liberal turn in EU policy because they delivered tangible economic benefits, not just for workers but also for governments and employers. Employer groups have often been among those arguing for the legal recognition and enforcement of labour standards, on grounds which include the stabilisation of wage bargaining arrangements and the promotion of workplace efficiency. ${ }^{8}$ Enacted labour laws are generally the result of political compromises, rather than simply the assertion of workers' interests over those of other constituencies.

Economic theory suggests that labour laws have a number of economic effects, some positive, some negative. ${ }^{9}$ Depending on the context, they can be effective in dealing with certain market failures, and thereby promote more efficient contracting. Efficiency wage and gift-exchange models imply that it is in employers' interests to offer job security and seniority-related benefits to workers in return for a continuing commitment to the firm, in circumstances where firm-specific rents can be generated through co-operation. ${ }^{10}$ Worker voice can provide a basis for generating loyalty, and for mitigating the effects of restructurings on worker commitment. Laws on employment protection and freedom of association can assist efficient contracting by providing workers with an external benchmark against which firms' promises to respect job security and worker voice can be measured and enforced, thereby enhancing the credibility of employer commitments. These laws can also facilitate

8 M. Barry, M. Michelotti and C. Nyland, 'Protectionism, Common Advocacy and Employer Interests: Business Contribution to Labour Regulation in Australia', in C. Arup, P. Gahan, J. Howe, R. Johnstone, R. Mitchell and A. O'Donnell (eds.), Labour Law and Labour Market Regulation (Sydney: Federation Press, 2006), pp. 43-66.

9 G. Bertola, 'Labour Market Regulation: Motives, Measures, Effects', Working Paper, ILO Conditions of Employment and Work Research Series (Geneva: ILO, 2009).

10 G. Akerlof, 'Labor Contracts as Partial Gift Exchange' (1982) 97 Quarterly Journal of Economics 543-69. 
signalling by employers willing to co-invest with workers in firm-specific knowledge and skills, thereby reducing search costs and enhancing labour mobility. ${ }^{11}$

Empirical evidence supports these claims, and suggests that labour law rules can have efficiency-enhancing effects, although these may be dependent on the presence of complementary institutions in product and financial markets. Several studies have found that a higher level of legal employment protection is correlated with a greater degree of innovation at firm level, as measured by patenting rates and investment in $\mathrm{R} \& \mathrm{D} .{ }^{12}$ This finding can be interpreted in various ways, but appears to show that high employment protection regimes induce a higher level of risk-sharing and co-investment in product and process innovation by employers and workers. Labour productivity more generally is positively related to high levels of employment protection and to legally mandated worker representation. ${ }^{13}$ There is only a weak empirical case at best for the claim that strong labour laws induce unemployment, and any such impact is weak by comparison with those of other institutional and macroeconomic policy variables. ${ }^{14}$

Studies which analyse the relationships between labour law regulation and related aspects of the institutional framework are also revealing. There is evidence to suggest that the benefits of product market deregulation, in terms of increased productivity, are dependent on the maintenance of a high level of employment protection, ${ }^{15}$ and that the positive impact

11 D. Levine, 'Just-cause Employment Policies in the Presence of Worker Adverse Selection' (1991) 9 Journal of Labor Economics 294-305.

12 W. Koeniger, 'Dismissal Costs and Innovation' (2005) 88 Economics Letters 79-85; V. Acharya, R. Baghai-Wadji and K. Subramanian, 'Labor Laws and Innovation', NBER Working Paper No. 16484, 2010; V. Acharya, R. Baghai-Wadji and K. Subramanian, 'Wrongful Discharge Laws and Innovation', Working Paper, NYU-Stern Business School, 2010; R. Griffith and G. McCartney, 'Employment Protection Legislation, Multinational Firms and Innovation', IFS Working Paper W10/01, 2010; F. Belloc 'Law, Finance and Innovation: the Dark Side of Shareholder Protection', Working Paper No. 583, Department of Economics, University of Siena, 2010.

13 Belloc, 'Law, Finance and Innovation'; F. Lucidi and A. Kleinknecht, 'Little Innovation, Many Jobs: an Econometric Analysis of the Italian Labour Productivity Crisis' (2011) 34 Cambridge Journal of Economics 525-46.

14 L. Baccaro and D. Rei, 'Institutional Determinants of Unemployment in OECD Countries: Does the Deregulatory View Hold Water?' (2007) 61 International Organization 52769; D. Baker, A. Glyn, D. Howell and J. Schmitt, 'Labour Market Institutions and Unemployment: A Critical Assessment of Cross-country Evidence', in D. Howell (ed.) Fighting Unemployment: The Limits of Free Market Orthodoxy (Oxford University Press, 2005).

15 D. Gatti, 'Macroeconomic Effects of Ownership Structure in OECD Countries' (2009) 18 Industrial and Corporate Change 901-28. 
of labour regulation on productivity is enhanced in 'co-ordinated market' systems characterised by 'blockholder' capital, which, in contrast to diversified capital, is locked into a long-term relationship with the firm. If this is the case, the interaction between competition law, worker protection and shareholder rights becomes a critical issue in understanding the effects of the legal framework.

The longitudinal aspect of the leximetric Labour Regulation Index constructed at the Cambridge Centre for Business Research ${ }^{16}$ makes it possible to test for both the short-run and long-run effects of legal change and to identify the direction of causality between law and the economy, using time-series econometric methods. Analysis ${ }^{17}$ suggests that there was a long-term positive impact of increases in working time protection on employment in France, and a similar impact on both employment and productivity in Germany. The tightening of dismissal protection in the US which resulted from the Warker Adjustment and Retraining Notification Act (WARN $)^{18}$ is correlated with an increase in productivity but a reduction in employment. These results imply that labour law regulation may have positive economic impacts, depending on context. In the US case, gains from increased productivity were to some extent offset by a fall in employment, suggesting that while there may have been more efficient contracting at firm level, more careful screening by firms resulted in the displacement of some workers into unemployment. No such disemployment effect was observed in Germany, possibly as a result of the presence there of sector-wide vocational training schemes.

If a growing body of evidence points to the positive contribution of labour regulation to productivity and competitiveness of firms even under conditions of neo-liberal policy ascendancy, a less optimistic scenario for labour law emerges when the focus shifts to its impact on equality. Between the early 1970s and the mid-2000s, there was a substantial fall in the 'wage share', that is, the share of national income devoted to wages as opposed to profits, across developed countries, which was especially marked in the co-ordinated market systems (Table 8.1). These countries also experienced the largest falls, in proportional terms, in union density,

16 Deakin, Lele and Siems, 'The Evolution of Labour Law'.

17 S. Deakin and P. Sarkar, 'Assessing the Long-run Economic Impact of Labour Law Systems: A Theoretical Reappraisal and Analysis of New Time Series Data' (2008) 39 Industrial Relations Journal 453-87.

18 The Warn Act (29 U.S.C. $\$ \$ 2101-2109$ ) protects employees, their families and communities by requiring most employees with 100 or more employees to provide sixty calender day advance notification of plant closings and mass lay-offs of employees. 
Table 8.1 Wage shares in selected countries, 1970-2006

\begin{tabular}{lcccc}
\hline \hline & France & Germany & UK & US \\
\hline 1970 & 0.76 & 0.73 & 0.70 & 0.69 \\
1980 & 0.79 & 0.75 & 0.69 & 0.70 \\
1990 & 0.70 & 0.69 & 0.71 & 0.68 \\
2000 & 0.67 & 0.70 & 0.69 & 0.69 \\
2006 & 0.67 & 0.66 & 0.69 & 0.66 \\
\hline \hline
\end{tabular}

Source: IMF.

Table 8.2 Union density and collective bargaining coverage rates from 1970 in selected countries

\begin{tabular}{lcllll}
\hline \hline & France & Germany & UK & EU & US \\
\hline Density & & & & & \\
1970 & 21.7 & 32.0 & 44.8 & 37.8 & 23.5 \\
1980 & 18.3 & 34.9 & 50.7 & 39.7 & 19.5 \\
1990 & 10.1 & 31.2 & 39.3 & 33.1 & 15.5 \\
2000 & 8.2 & 25.0 & 29.7 & 27.3 & 12.8 \\
2003 & 8.3 & 22.6 & 29.3 & $26.3^{*}$ & 12.4 \\
Coverage & & & & & \\
2004 & $95.0^{* *}$ & $63.0^{* * *}$ & 35.0 & & 13.8 \\
\hline \hline
\end{tabular}

* Figures for 2002. ${ }^{* *}$ Figures for 2003. ${ }^{* * *}$ Figures for 1997.

Source: Uissier, 2006.

although this was to some degree offset by a continuing role for collective bargaining coverage, as sector-level collective agreements remained in place notwithstanding reductions in union membership (Table 8.2).

It appears that while labour law deregulation did not occur on a major scale in the large industrial economies of Western Europe and North America during the period of neo-liberal policy ascendancy, the maintenance of legal protections for workers and unions did not prevent significant union decline. There are a number of forces at work in the fall in the wage share, but a highly likely cause is the reduced ability of unions to capture a high share of profits in sectors characterised by increased product market competition and growing exposure of firms to 
172

SIMON DEAKIN AND ARISTEA KOUKIADAKI

international competitive pressures. Union decline has also contributed to growing polarisation, within the share of national wealth allocated to wages, between higher and lower earners.

An additional factor in growing inequality has been the pressure on companies to pay out profits to shareholders in the form of higher dividends and share buy-backs. In most years since the early 1980s, net flows of equity capital into corporate investment have been negative in the US and UK, indicating that the amounts paid out to shareholders in the form of dividends and share repurchases exceeded, in aggregate terms, sums raised on equity markets through new listings and share flotations. ${ }^{19}$ This diversion of profits from wages to dividends and share buy-backs is a further factor in growing income inequality, as notwithstanding the greater dispersion of equity ownership associated with the increase in institutional shareholdings in developed economies for most of the postwar period (a trend which was reversed in the UK in the 2000s), share ownership continues to be highly skewed in favour of the wealthy. ${ }^{20}$

These trends put into perspective the relative stability of labour law regulation in the developed economies. Even where the formal law has changed little, its effectiveness in practice was diminished by union decline, in particular in systems where enforcement of labour standards did not depend on State bodies such as labour inspectorates.

Thus labour law regulation survived the period of growing neo-liberal policy dominance within the $\mathrm{EU}$, but in a form in which it was unable to fulfil its traditional goals of redistribution, and in a context where its role in co-ordinating the employment contract was increasingly called into question by its reduced effectiveness in practice. Labour law rules played a role that was subordinate to finance within the framework of neo-liberal economic policy. The contradictions of that policy were to become apparent with the onset of the financial crisis.

\section{Deregulation and feedback loops between financial and labour markets during the crisis}

If the crisis of 2007-8 originated in the financial sector, it was not simply a crisis of finance or of the way it was regulated. Feedback loops between

19 T. Van Treck, 'A Synthetic Stock-flow Consistent Macroeconomic Model of Financialisation' (2009) 33 Cambridge Journal of Economics 467-93.

20 S. Jacoby, 'Finance and Labor: Perspectives on Risk, Finance and Democracy' (2008) 30 Comparative Labor Law and Policy Journal, 17-65. 
finance and the wider economy played a role in generating the fragility in financial systems which triggered the crisis. Connections between labour and financial markets meant that regulatory mismatches were transmitted from one market context to another, reinforcing and deepening the crisis. This process is still playing out at the time of writing (the autumn of 2012).

The crisis began not as a result of excessive regulation in the labour market, but because of deregulation and lax supervision in financial markets. In the financial context, the pro-shareholder value stance of corporate governance reforms from the early 1990s onwards, coupled with a 'light touch' approach to financial regulation, in particular in the US and the UK, created the conditions for the extreme market instabilities of the kind which culminated in the credit crunch and crash of $2007-8 .{ }^{21}$ When the crisis struck, the state had to assume the role of guarantor of last resort, as no other means were available to resolve financial claims which were beyond the capacity not just of individual firms but of the market as a whole.

Financial deregulation followed by crisis and the intervention of the State as guarantor of last resort had been predicted by Minsky. ${ }^{22}$ In his model, financial crises are an endemic part of a market economy, resulting from the misalignment of the incentives of firms, financial institutions and regulators. Surplus liquidity puts pressure on regulators to liberalise the rules governing financial transactions, which further increases the exposure of financial institutions to risk. Central banks have little option but to underwrite the exposure of financial firms and to stand behind them in the event of a system-wide failure, notwithstanding the risks of 'moral hazard'.

Thus the financial crash which began with the loss of liquidity in credit markets in the autumn of 2007 was endogenously generated, in the sense of originating in the mismatch between the risks being run by market actors and the limited contractual and regulatory means they had for dealing with them. Feedback loops between financial and labour markets then helped to create the conditions for the crisis and ensured that its effects were widely felt. Increased wage inequality was compensated for by growing household indebtedness, which further contributed to fragility in the financial system through its effect on asset price

21 S. Deakin, 'Corporate Governance and Financial Crisis in the Long Run', in P. Zumbansen and C. Williams (eds.), The Embedded Firm (Cambridge University Press, 2011), pp. 1541.

22 H. Minsky, Stabilising an Unstable Economy (New Haven, CT: Yale University Press, 1986). 
inflation. ${ }^{23}$ The effects of the 'shock' were transmitted in the first instance from the financial markets to the State, which took on the liabilities of the failed banks and financial sector firms, and from there to the labour market, in the form of the 'structural adjustments' to the welfare state and collective bargaining which were presented as necessary for financial stabilisation. ${ }^{24}$

The transmission of shocks from financial markets to the rest of the economy could have been prevented or at least mitigated by measures taken by the State to maintain credit flows to firms and to place a floor under wages and employment. To begin with, this was more or less what happened as governments reacted to the immediate effects of the crisis. However, with one or two exceptions, counter-cyclical interventions were limited in their effects, and short-lived. The reversion to 'orthodox' policies was particularly marked in the EU.

The sovereign debt crisis which began in late 2009 has been the occasion for the further intensification of neo-liberal policies in Europe. The sovereign debt crisis, like the initial financial crash, was the direct result of neo-liberal regulatory failures originating in the policies and institutions of the pre-crisis period. These failures were embedded in the institutional structure of the EU from the early 1990s onwards, with the Maastricht Treaty the turning point.

After the Maastricht Treaty, as we have seen, the institutional design of the European Union reflected the neo-liberal policy goals of price stability and market-based resource allocation. During this period, EU internal market law came to regard differences in national regulatory frameworks as distortions of competition, resulting in deregulatory pressure on labour law, while competition law was used to fragment and weaken the State as an economic actor beyond its role as a guarantor of market access. ${ }^{25}$ Member States in the Eurozone gave up exchange rate flexibility in return for low borrowing costs and improved access to foreign capital. The European Central Bank used monetary policy to discipline wage growth, a policy complemented by social pacts in several Member States which pegged nominal wage increases to below the level of productivity

23 Van Treck, 'A Synthetic Stock-flow'.

24 K. Armingeon and L. Baccaro, 'Political Economy of the Sovereign Debt Crisis: The Limits of Internal Devaluation' (2012) 41 Industrial Law Journal 254-75.

25 S. Deakin, 'The Lisbon Treaty, the Viking and Laval Judgments and the Financial Crisis: in Search of New Foundations for Europe's "Social Market Economy", in N. Bruun, K. Lörcher and I. Schömann (eds.), The Lisbon Treaty and Social Europe (Oxford: Hart Publishing, 2012), pp. 19-44. 
gains. ${ }^{26}$ These policies were responsible for the imbalances between the creditor and debtor States which gave rise to the sovereign debt crisis. The current indebtedness and lack of competitiveness of the southern States is the consequence not just of their over-reliance on low-cost foreign loans and private-sector borrowing to stimulate growth in the years immediately prior to the crisis, but of the deflationary policies pursued by the northern States. ${ }^{27}$

In response to the crisis, policies of 'internal devaluation' have been pursued within the EU, as a result of conditions imposed by the 'Troika' of the European Commission, European Central Bank and IMF in return for loans to the debtor States. These policies entail restrictions on social security benefits and cuts to state education and health provision, as well as minimum wage reductions, extensions to the working week, the removal of legal support for multi-employer collective bargaining, and the encouragement of fixed-term and temporary employment through changes to employment protection legislation. In the absence of exchange rate flexibility, internal devaluation is being presented as the only feasible route to the restoration of the competitiveness, in terms of unit labour costs, of the southern European Member States in relation to Germany and other Eurozone States, including Austria and Finland, which are closely integrated with the German economy. This competitiveness gap is in part the result of the social pacts which depressed wage growth in the northern Member States, as well as the high productivity achieved in part through the institutionalisation of workplace co-operation in those countries, and not replicated elsewhere. ${ }^{28}$ Yet the focus of reforms has been exclusively on the labour law regimes of the southern Member States, as we shall now explore.

\section{The response to the crisis: internal devaluation and labour law in the Eurozone States}

\section{A. Underlying rationale and the process of change in national labour} law systems

The international loan agreements that were concluded between the Troika of creditors and the affected EU Member States (Greece, Ireland and Portugal) were accompanied by a series of Memoranda that outlined a

26 A. Johnston and B. Hancké, 'Wage Inflation and Labour Unions in EMU' (2009) 16 Journal of European public policy 601-22.

27 Armingeon and Baccaro, 'Political Economy of the Sovereign Debt Crisis'.

28 Johnston and Hancké, 'Wage Inflation and Labour Unions'. 
range of reforms in the national economic and legal systems. On the basis that the EU Member States' membership of the Eurozone did not allow for currency devaluation, the underlying rationale for the introduction of such measures was the need to initiate a process of 'internal devaluation' to restore the competitiveness of the national economies. In this context, public deficit reduction measures were coupled with in-depth structural reforms that aimed at the reform of social security and labour law. ${ }^{29}$ The structural reforms were consistent with the dominant view that the lack of competitiveness of the national economies was due to labour market rigidities and the high degree of employment protection legislation. ${ }^{30}$ Despite the fact that Spain and Italy have not so far concluded any loan agreements with the Troika, significant pressures were exerted by the ECB and the European Commission with a view to introducing similar measures in the domestic labour markets there as well. In Italy, a number of policies that have been introduced since 2011 bear strong resemblance to a 'secret letter' to the then Italian Prime Minister that was signed jointly by both the incoming and outgoing Presidents of the ECB. ${ }^{31}$ The letter included recommendations for promoting labour market flexibility in individual labour law and called for changes in the collective bargaining system in order to promote productivity. In Spain, the insertion of limitations to public deficit levels in Article 135 of the Constitution was attributed to pressures from other EU Member States and the ECB. ${ }^{32}$

While international institutions influenced the nature and extent of labour market reforms pursued in the EU Member States mostly affected by the sovereign debt crisis, there was limited evidence of dialogue and deliberation in the political and industrial relations systems at domestic

29 Due to space limitations, the discussion in this section concentrates on the Member States that introduced structural reforms in the area of labour law in line with recommendations from EU institutions and/or as a result of a loan agreements concluded with the IMF, the ECB and the European Commission. The analysis concentrates on changes in labour law and does not discuss the measures introduced in the areas of public sector employment and social security.

30 For an analysis, see C. Teissier, 'Quelles perceptions nationales de la crise?', in M. C. Escandre Varniol, S. Laulom and E. Mazuyer (eds.), Quel Droit Social dans une Europe en Crise? (Brussels: Larcier, 2012), pp. 344-50.

31 See www.corriere.it/economia/11_agosto_08/lettera-trichet_238bf868-c17e-11e0-9d6c 129de315fa51.shtml (accessed 4 October 2012).

32 J. M. Miranda Boto and R. Rodriguez Contreras, 'The Case of Spain', in M. C. Escandre Varniol, S. Laulom and E. Mazuyer (eds.), Quel Droit Social dans une Europe en Crise? (Brussels: Larcier, 2012), pp. 131-55, at 132. See also A. Baylos Grau and F. Trillo Parraga, 'Spain: The Impact of Anti-crisis Measures and the Social and Employment Situation', European Economic and Social Committee Worker's Group (Brussels, 2012), pp. 3-4. 
level. ${ }^{33}$ The case of Greece helps illustrate this point. ${ }^{34}$ The lack of ratification of the first loan agreement by the Greek Parliament was coupled with the absence of social dialogue with respect to the changes required in the labour market. The then Greek Government held that it was not possible to accommodate participatory methods when Greece was about to default on its loans. ${ }^{35}$ But also later, no account was taken of the agreement reached between the Greek social partners in anticipation of the austerity measures associated with the second loan agreement. The lack of any influence of the social partners not only illustrated the unilateral character of the reforms but also deprived policy-makers of all the information necessary for effective policy design, and arguably hindered the chances of maintaining balance in such policies by mitigating their adverse effects on the most vulnerable groups. ${ }^{36}$ In the absence of due regard to social dialogue procedures, there is evidence of 'legal mobilisation' ${ }^{37}$ on the part of Greek and Spanish trade unions at national and international level, with recourse to the ILO and the European Committee of Social Rights. $^{38}$

\section{B. Changes in employment protection legislation}

In order to promote a competitive climate through increasing labour market flexibility, youth employment and creating new forms of work, wide-ranging changes were introduced in the national systems of individual labour law. The reforms targeted a number of issues related to

33 For a discussion on this see P. Vielle, 'La légitimité des mesures de droit social en temps de crise', in M. C. Escandre Varniol, S. Laulom and E. Mazuyer (eds.), Quel Droit Social dans une Europe en Crise? (Brussels: Larcier, 2012), pp. 365-77. See also K. Armingeon and L. Baccaro, 'The Sorrows of Young Euro: The Sovereign Debt Crisis of Ireland and Southern Europe', in N. Bermeo and J. Pontusson (eds.), Coping with Crisis: Government Responses to the Great Recession (New York: Russell Sage, 2012).

34 For an analysis, see A. Koukiadaki and L. Kretsos, 'Opening Pandora's Box: The Sovereign Debt Crisis and Labour Market Regulation in Greece' (2012) 41 Industrial Law Journal, 276-304.

35 ILO, Report on the High Level Mission to Greece (Geneva: ILO, 2011), p. 27.

36 Y. Ghellab and K. Papadakis, 'The Politics of Economic Adjustment in Europe: State Unilateralism or Social Dialogue?', in ILO (ed.), The Global Crisis: Causes, Responses and Challenges (Geneva: ILO, 2011), pp. 81-91, 90.

37 T. Colling, 'What Space for Unions on the Floor of Rights? Trade Unions and the Enforcement of Statutory Individual Employment Rights' (2006) 35 Industrial Law Journal $140-60$.

38 For details on the Greek case, see Koukiadaki and Kretsos, 'Opening Pandora's Box'; for details on the Spanish case, see S. Clauwaert and I. Schomann, 'The Crisis and National Labour Law Reforms: A Mapping Exercise’, ETUI Working Paper 2012.4, Brussels, 2012. 
employment protection legislation, including dismissal compensation, collective redundancies, flexible forms of employment and contracts for young workers.

First, on the basis of the need for reduction of labour costs, significant regulatory alterations took place in the regulation of individual and collective dismissals. In Greece, Spain and Portugal the notification period for individual dismissals and dismissal compensation was reduced. ${ }^{39}$ In Spain and Portugal, the grounds for dismissal were also extended. In Italy, recent legislation provides for the replacement of reinstatement with the provision of compensation in the case of unlawful dismissals due to economic or other objective reasons; caps were also introduced with respect to dismissal compensation in certain cases. ${ }^{40}$ With respect to collective dismissals, changes were introduced concerning the thresholds applicable to collective dismissals in Greece. ${ }^{41}$ In other EU Member States, amendments were made to the procedures governing redundancies by reducing advance notice (Spain and Portugal) and by removing the requirement for authorisation of redundancies by the public authorities (Spain). ${ }^{42}$

Further, a number of changes were introduced in atypical forms of employment. In Greece, the probationary period of employment contracts without limit was increased from two to twelve months, and as such introduced into the labour market a new form of fixed-term employment contract of one year's duration. ${ }^{43}$ Similarly, in Spain a new type of contract that provides social security benefits (tax breaks and reductions in social security contributions) as well as labour law benefits (one-year probationary period with the possibility to end the contract at will during that time) was created with the aim of encouraging companies to recruit certain categories of employees (unemployed and women). ${ }^{44}$ Changes also

39 In Greece, see Act 3863/2010. In addition, during negotiations in autumn 2012, the Troika demanded further changes, namely the reduction of the notification period from six to three months, and the reduction of dismissal compensation from twenty-four months to twelve months maximum. In Portugal, the amendments in dismissal legislation aimed specifically at aligning (by reducing) dismissal compensation to the average levels in the EU and providing for a common legal framework for open-ended and fixed-term contracts alike (see Act 53/2011 and Act 23/2012). In Spain, see Royal Decree 10/2010 and Act $3 / 2012$.

40 See Act 92/2012. The judge can still decide for reinstatement when the economic reasons were found 'patently non existent'.

41 Act 3863/2010. 42 Act 3/2012. 43 Act 3899/2010.

44 This type of contract can be used only by companies that employ less than fifty employees and provides the benefit of lower social security contributions on the part of the employers (see Act 3/2012). The possibility for concluding such contracts will remain in force until the unemployment rate falls to under 15 per cent. 
took place with respect to fixed-term work. ${ }^{45}$ In Greece, the maximum duration of fixed-term contracts was extended from two to three years. In Portugal, the duration of fixed-term contracts was extended from six months to three years. ${ }^{46}$ In Spain, Act 3/2012 stipulated the conversion of fixed-term contracts to open-ended ones if employment exceeds two years of service under successive contracts. In addition, Royal Decree 1796/2010 laid down provisions for the operation of private placement agencies. In Italy, Act 92/2012 stipulates that there is no need for the specific indication of an objective business need in the case of first fixed-term contracts, for a maximum period of twelve months.

Managerial prerogative was reinforced by amendments in the regulation of working time. In Portugal, Act 23/2012 provided for the reduction of additional overtime by 50 per cent, the elimination of compensatory time-off and a number of public holidays and expanded the legal regime of 'working time account' by allowing the conclusion of agreements between the employer and individual employees and the application of the scheme to employees not covered by collective agreements. ${ }^{47}$ In addition, the legal framework concerning the temporary reduction of working time and suspension of employment due to business crisis was extended to allow more flexibility for the employer. ${ }^{48}$ In Italy, the Stability Act 2012 provided for the possibility of including flexibility clauses in part-time contracts empowering the employer to modify the duration of the working time or its distribution. ${ }^{49}$ In Spain, Act 3/2012 introduced a number of measures designed to promote working time flexibility, including the abolition of the prohibition of overtime in part-time work; the extension of the scope for flexible allocation of working hours over a year; ${ }^{50}$ and the abolition of a requirement on employers to obtain permission from the public authorities in order to temporarily reduce working hours or to implement temporary lay-offs. In addition, employers acquired the right to move employees within professional groups, if this can be justified for

45 In Italy, Act 92/2012 aims to limit the improper use of flexible contracts; for an analysis, see E. Ales, 'The Italian Reform of the Labour Market in a Growth Perspective', (2012) 3 European Labour Law Journal, 75.

46 Act $3 / 2012$.

47 For a discussion, see R. Canas da Silva, 'Portuguese Labour Law Reform: Developments in 2011-2012', (2012) 3 European Labour Law Journal, 86.

48 See Act 23/2012. 49 Article 22(4).

50 Royal Decree $7 / 2010$ had initially provided that collective agreements should identify a minimum and maximum limit of working time that could be distributed irregularly throughout the year. 
technical or organisational reasons. ${ }^{51}$ In Greece, the period of short-time work was extended to nine months per year and the scope for the conclusion of agreements between employers and unions on working time arrangements at company level was extended. ${ }^{52}$ In addition, new possibilities were provided for the determination of working time arrangements, including the extension of the time period for the calculation of working time from four to six months and the provision of compensatory time off instead of pecuniary payment for overtime. ${ }^{53}$ More recent demands by the Troika include the introduction of greater flexibility in weekly working time arrangements, including controversially an increase of working days from five to six.

\section{Changes in wage-setting and collective labour law}

Particular efforts have been made to alter existing systems of wage setting as well as procedures for collective bargaining, mediation and arbitration. The changes were in line with the need to ensure wage moderation but also to amend essential features of the national collective labour law systems.

In terms of wage moderation, interventions were made in Greece, in the context of the first loan agreement, with respect to the validity of arbitration awards and the negotiation of collective agreements. With the objective of promoting youth employment, significant changes regarding minimum wage levels of young people aged fifteen to twenty-four were introduced in the context of the first loan agreement. The changes provided for the exclusion of young workers and previously long-term unemployed from the scope of the national collective agreement and from generally binding provisions on minimum wages and conditions of work. ${ }^{54}$ Following the second loan agreement, a realignment of the minimum wage level, as determined by the national general collective agreement, was introduced, implying a 22 per cent wage cut at all levels. A further 10 per cent cut for youth, which applied generally without any restrictive conditions (under the age of 25) was also stipulated, and the minimum wage for apprentices was set at 68 per cent of the level determined by the national agreement. A freeze in minimum wage levels was also prescribed until the end of the programme period (2015). In addition,

51 Act $3 / 2012$.

52 It is important to note that so-called 'associations of persons' acquired the right to negotiate working time arrangements.

53 Act 3986/2011. 54 Act 3845/2010 and Act 3863/2010. 
the legislative intervention in the level of wages, in the form of clauses in the law and in collective agreements that provide for automatic wage increases dependent on time, including those based on seniority, were suspended, until such time as unemployment falls below 10 per cent. ${ }^{55}$ In Portugal, Act 23/2012 imposed restrictions on collective bargaining, prohibiting the provision of more favourable terms through collective agreements for two years. In Ireland, the 2009 recovery plan included a suspension of the private sector pay agreement negotiated under the so-called 'Towards 2016' social partnership agreement, except in certain defined circumstances. However, the 12.5 per cent cut in the minimum wage for new hires, which had become applicable in February 2011, was reversed when the Fine Gael Labour coalition came to power in March $2011 . .^{56}$

A range of measures were also introduced with the objective of moving wage-setting closer to the company level. In Greece, recent legislation provided that all firms have the capacity to conclude firm-level collective agreements that derogate in pejus from sectoral-level agreements. ${ }^{57}$ In addition, during the application of the Medium-Term Fiscal Strategy Framework, a temporary suspension took place of the application of the principle of favourability in the case of the concurrent implementation of sectoral and firm-level collective agreements. There was suspension, for the same period, of the extension of sectoral and occupational collective agreements. ${ }^{58}$ Substantial changes were also required, as a result of the second loan agreement in 2012, with respect to the length of collective agreements and their 'after-effect' period. Under the new legislation, all collective agreements can only be concluded for a maximum duration of three years. Collective agreements that have expired will remain in force for a maximum period of three months. ${ }^{59}$ If a new agreement is not reached, after this period remuneration will revert back to the basic wage, as stipulated in the expired collective agreement, plus specific allowances

55 Act 6 of 28 February 2012 of the Ministerial Council.

56 There is some evidence to suggest that Ireland has tried to place safeguards on the extent of reforms in the labour market. While two-thirds of fiscal adjustments have come from expenditure cuts, new resources have been provided for the purpose of training, orientation and employment services for the unemployed. In addition, social dialogue led to the so-called 'Croke Park Agreement', which commits the government to maintaining existing pay rates and avoiding compulsory redundancies in return for a broad trade union and employee commitment to reform and change.

57 Act 4024/2011. 58 Act 4024/2011.

59 Act 6 of 28 February 2012 of the Ministerial Council. 
until replaced by those in a new collective agreement or in new or amended individual contracts. ${ }^{60}$

Similarly, in Italy and in line with the ECB recommendations, as outlined in the 'secret letter', legislation provided for the first time the possibility for the so-called 'proximity agreements' at company and territorial level to derogate from the statutory provisions on 'all aspects of labour organisation and production', including among others: working hours, fixed-term work contracts, part-time work contracts, temporary agency work, hiring procedures and dismissals. ${ }^{61}$ While the resulting agreements still have to conform to the Italian constitution, EU norms and international requirements, the changes represented a radical shift concerning the role of legislation in setting down labour standards. ${ }^{62}$ In Portugal, the Memorandum foresaw major changes in the collective bargaining system with the objective of 'organised decentralisation', including the creation of a possibility for collective agreements to define conditions under which Works Councils can negotiate functional and geographical mobility, working time arrangements and remuneration, and the decrease of the firm size threshold to 150 workers for unions to delegate power to conclude collective agreements to Works Councils. Similar to Greece, there were also requirements for the reduction of the 'after-effect' period of collective agreements. ${ }^{63}$

In Spain, the Government enacted a series of labour laws that modified collective bargaining rules. The most recent decentralised collective bargaining to a greater degree than the previous reforms brought in by the previous government. Similar to the previous legislation (Royal Decree 7/2011), the new legislation (Act 3/2012) gives precedence to companylevel agreements over sectoral and provincial-level agreements in areas

60 The allowances covered include those based on seniority, number of children, education and exposure to workplace hazards.

61 With some exceptions (such as discriminatory dismissal, pregnant workers, mothers with babies under the age of one, dismissal during maternity leave, or dismissal of employees who have requested parental or adoption leave). The 2009 agreement signed by Confindustria, Uil and Cisl introduced the possibility for 'opting-out clauses' from the national agreements in order to cope with territorial or economic crises or to foster economic growth.

62 For an analysis of this as well as the Fiat agreements that made use of this option, see P. Loi, 'The Case of Italy', in M. C. Escandre Varniol, S. Laulom and E. Mazuyer (eds.), Quel Droit Social dans une Europe en Crise? (Brussels: Larcier, 2012), pp. 261-82, 268-70.

63 Ministry of Finance, Memorandum of Understanding on Specific Economic Policy Conditionality, (Ministry of Finance, 2012). The Portuguese Government intends to introduce reforms in these areas within 2012 and 2013. 
such as pay, working time, work organisation and work-life balance. The main change from previous legislation is that company agreements take precedence over sectoral agreements, even if agreements at a higher level state otherwise. ${ }^{64}$ Act 3/2012 also introduced the possibility for employers to opt out from collective bargaining if the enterprise records a drop in its revenues or sales for six consecutive months. It also provided that the 'after-effect' period of collective agreements should be limited to one year. ${ }^{65}$ Legislation that was passed earlier (Royal Decree 7/2011) had also introduced the requirement that all collective agreements should introduce specific time limits for the negotiation of a new agreement.

Beyond promoting company-level bargaining, changes were recorded with respect to the criteria for employee representation. In Greece, so-called 'associations of persons' were given the capacity to conclude enterprise-level collective agreements that can derogate in pejus. ${ }^{66}$ The representativeness of the 'association of persons', which are not trade unions, nor are they regulated by any of the guarantees necessary for their independence, is particularly problematic, especially in the context of small and medium enterprises that make up the majority of Greek companies. ${ }^{67}$ In Italy, it was originally planned that 'proximity agreements' could be signed by 'union representation structures operating in the company'. The ambiguity in the term used created the risk that weak enterprise-level unions could enter into agreements with employers, contributing thus to different levels of employment protection depending on the socio-economic situation of the region in which the enterprise was located. ${ }^{68}$ Article 8 of Act 148/2011 now provides that 'proximity agreements' should be signed by 'trade union organisations operating in the company following existing laws and interconfederal agreements', including the national agreement of 28 June $2011 .^{69}$ In Portugal, the

64 Royal Decree 10/2010 provided that in the absence of workers' legal representatives at company level and for the purpose of concluding collective agreements at that level, employees would be able to confer representation on a commission made up of a maximum of three members belonging to the most representative trade unions of the sector.

65 Until then and according to Article 86(3) of the Workers' Statute, a collective agreement that had expired would remain in force until a new agreement would be concluded.

66 Act 4024/2011.

67 This point was stressed by the ILO Report on the High Level Mission to Greece.

68 Loi, 'The Case of Italy', p. 268.

69 The intercofederal agreement of 28 June 2011 defined the criteria for union representativeness, provided for the general binding character of company agreements approved by a majority of unions/Works Councils and extended the possibilities for company-level derogations from the national collective agreements. In contrast to the 2009 agreement, 
2011 Memorandum called for amendments in the definition of the criteria for the extension of collective agreements, including the representativeness of the negotiating organisations, that are to be assessed by 'both quantitative and qualitative' indicators) and the issue of the extension of agreements to non-affiliated employers. ${ }^{70}$ Labour law reforms in the area of mediation and arbitration also took place. The 2012 reforms in Greece allowed for the first time recourse to arbitration only if both parties consent and arbitration is to be confined solely to the determination of the basic wage/salary. In Spain, Act 3/2012 introduced compulsory arbitration regarding the application or modification of collective agreements in the absence of voluntary bilateral application by the parties concerned.

More radical changes that affected the nature of national-level collective bargaining were also promoted. In the case of Greece, it was intended that the Government, together with social partners, would prepare a timetable for an overhaul of the national general collective agreement. The proposal was to replace wage rates set in the national general collective agreement with a statutory minimum wage rate legislated by the Government in consultation with social partners. It was made in order to 'bring Greece's minimum wage framework into line with that of comparator countries and allow it to fulfil its basic function of ensuring a uniform safety net for all employees. ${ }^{71}$ In Portugal, the Memorandum called for an independent review to examine how the tripartite concentration on wages can be reinvigorated with a view to defining norms for overall wage developments that take into account the evolution of the competitive position of the economy. ${ }^{72}$ Finally, in Ireland, in line with the stipulations in the Memorandum, a review of the framework of Registered Employment Agreements (REAs) and Employment Regulation Orders (EROs) took place recently by the Ministry for Enterprise, Trade and Innovation.

the 2011 agreement provides that derogation in pejus can only take place if there are no restrictions in place in the national collective agreement (Ibid., pp. 274-5).

70 Ministry of Finance, Memorandum of Understanding on Specific Economic Policy Conditionality.

71 Ministry of Finance, Memorandum of Economic and Financial Policies (Ministry of Finance, 2012), p. 22. During negotiations in autumn 2012, the Troika demanded that the new framework for the determination of the minimum wage should start to come into effect in April 2013.

72 Ministry of Finance, Memorandum of Understanding on Specific Economic Policy Conditionality. 
On the basis of the recommendations in the 'Duffy-Walsh review, ${ }^{73}$ the Industrial Relations (Amendment) Act 2012 set stricter conditions for the establishment and variation of EROs and REAs. ${ }^{74}$

Overall, the legislative changes in the area of labour law that accompany the loan agreements did not simply aim to restrict the level of wages and promote negotiated forms of flexibility but to increase managerial prerogative and dismantle, in line with the policy of 'internal devaluation', the system of collective bargaining.

\section{Beyond austerity?}

The European policy of enforced austerity does not address the causes of the sovereign debt crisis. Although Greece's fiscal position was unstable prior to 2009, this was not the case in other Member States subsequently exposed to the risk of sovereign debt default; they had largely observed the public deficit and debt criteria agreed at Maastricht. The public deficits which emerged in the course of 2009 were the result of the assumption by governments of liabilities incurred by financial sector firms, and of the effects of the recession triggered by the crash, in terms of falling tax revenues and rising social security expenditure. ${ }^{75}$ The claim that the competitiveness gap can be closed by cuts to wages and social welfare provisions alone is implausible, while the short-term consequences of attempting to do so include rapidly rising unemployment and bankruptcies and an intensification of the recession, which together are making it more difficult to service the sovereign debts of the southern Member States.

73 Ministry for Enterprise, Trade and Innovation, Independent Review of Employment Regulation Orders and Registered Employment Agreement Wage Settling Mechanisms (Dublin: Ministry for Enterprise, Trade and Innovation, 2011). The review found that the maintenance of the framework of the Joint Labour Committees and the REAs was necessary and justified but concluded that the system needed a radical overhaul and made a number of recommendations in order to make it more responsive to changing economic circumstances.

74 JLCs will be more restricted in the extent to which they can award changes in rates of pay and companies will be able to derogate from EROs in cases of financial difficulty. The Act also provides for Ministerial and Parliamentary oversight of the ERO/REA system and for clarifying the definition of 'participating parties' (i.e. employers and trade unions, or groups thereof).

75 Armingeon and Baccaro, 'The Sorrows of Young Euro'. 
Austerity policy simply takes to a further stage the logic of neoliberalism, which requires flexibility in labour markets to compensate for rigidities elsewhere, including, in this case, the effects of a strict monetary policy. The implications for European labour law if austerity policy continues are likely to be severe. Whether the policy can be maintained remains to be seen. There were signs, in the autumn of 2012, that it was becoming politically more difficult to sustain, as the restrictive conditions imposed by the Troika as part of the first wave of financial assistance programmes were seemingly being modified in the case of ECB support for Spain, and the IMF itself drew attention to the counter-productive nature of austerity policies.

The slowly dawning realisation, in Europe and elsewhere, that policies of austerity are not going to restore economic growth, and that the roots of the crisis lie in the institutions and mechanisms of the period of neoliberal ascendancy which preceded it, should lead to a reappraisal of previously accepted theories and prescriptions, of the kind which occurs once in a generation or so. How this will develop, and how long it will take for the log-jam in policy-making to shift, remain to be seen, but some emerging trends can be identified.

In this context, it is becoming clear that any prolongation of austerity measures along the lines of current Troika policies, let alone their institutionalisation through new legal structures culminating in possible amendments to the core Union treaties, will give rise to unsustainable social and political risks for the Union. Going forward, a number of scenarios need to be explored. A first, which could be described as regulated austerity, is that the Eurozone stays intact under the current institutional conditions of the 'Six Pack' and the Treaty on Stability, Coordination and Governance, but at the cost of depressed growth in the southern economies as austerity policies are implemented. Although regulated austerity has ultimate convergence as its aim, it is most unlikely that this will be realised, because of underlying differences in the economies of the Member States and the dominant policy of flatness in German remuneration rates. It may even contribute to an economic downturn and recession in northern Member States, as demand for exports from southern Member States will be depressed.

A second scenario, which is a version of a two-speed Europe, envisages the fragmentation of the Eurozone into a 'hard core' based around Germany, which will operate with a version of the single currency confined to a smaller number of economically-homogeneous member states, and a 'periphery' of other States whose membership of the Eurozone is either 
suspended or otherwise modified, to allow them some flexibility as they implement structural reforms designed to bring their costs into line with those of the core, or prospective, in the case of the current Euro-plus group. This model, which would come a step closer to being realised were Greece or another of the debt-affected Member States to leave the Eurozone, offers more flexibility than the first, but is not without its risks. It is likely to lead to further economic divergence and differential growth rates between 'core' and 'periphery'. It would embed economic and social disadvantage in the periphery States, but would also call into question the economic model of the core, as the competitiveness of a German-centred monetary union would be undermined by the strengthening of the single currency once it was confined to this group.

The third scenario is that of solidaristic integration. This implies the deepening of EU integration on the basis of new forms of solidarity, involving an expansion of the European budget to deliver fiscal transfers from core to periphery, and replacement of the model of competition among national legal systems by the harmonisation of the Member States' social and fiscal laws. This approach represents the Union's best option for the reduction in differentials in competitiveness between the Member States, and hence for mitigating the social effects of uneven development between them.

In suggesting the third route, we do not think we are making a proposal which is anything other than severely practical. The first two options represent a greater risk to the wider project of European economic and political integration. The third route will come to seem more plausible if, as seems likely, policies of austerity lead to a widening of imbalances between the creditor and debtor States. To reverse current policy will necessitate a rethinking of the semi-autonomous role of the ECB and a shift in its mandate to enable it to pursue a wider range of economic goals, including full employment and social cohesion. It will also entail a reappraisal of the deregulatory emphasis within the Union's internal market programme and the European Employment Strategy, as determined by the Europe 2020 strategy. For labour law, it opens up the possibility of revival, as labour standards at both national and EU levels are seen as having a core role to play in underpinning growth-related economic strategies. At national level, the need for reversing the deregulatory labour market measures in all Member States affected is a crucial first step. In their place, wider policies, which are adopted with the participation of all stakeholders in the societies concerned, and which are based on a reconfiguration of the national productive models on the basis of a 
different understanding of the relationship between labour law regulation and related aspects of the institutional framework can be considered. At EU level, the renewal of support for substantive rights in the area of employment protection but perhaps more significantly for procedural rights via the encouragement of collective voice and action will provide a floor for pursuing policies that recognise the significance of labour regulation for redistribution and ultimately equality. 